\title{
Nadine Ly, profesora: recuerdos de una alumna desde las aulas de la Universidad Bordeaux Montaigne
}

\section{Lise Segas \\ Université Bordeaux Montaigne AMERIBER-CHISPA}

Cuando era tan solo una joven que empezaba a estudiar las letras hispánicas, me enteré de que en la Universidad llamada por aquel entonces Michel de Montaigne Bordeaux 3 la profesora Nadine Ly dictaba una clase sobre la Segunda parte del ingenioso caballero Don Quijote de la Mancha. Quisiera precisar que cursé los primeros ańos de carrera en una institución particular: las "clases preparatorias a las grandes escuelas», vía muy selectiva en Francia y paralela a la Universidad. Allí se forma a los alumnos seleccionados para que luego concurran al examen de ingreso de la Escuela Normal Superior.

Transcurrido un bienio, y después de presentarme por vez primera a dicho examen, de veras difícil, decidí no repetir la experiencia; a diferencia de lo que suelen hacer muchos otros, con buenos resultados. Mis motivaciones no obedecían a un afán de rebelión contra un sistema elitista o al tradicional agotamiento intelectual de los que se empeñan en este camino, sino a una noticia que me había llegado por casualidad: el próximo año iba a ser el último que Nadine Ly impartiría la lección sobre el segundo Quijote. Y por más que trataron de disuadirme mis maestros de las "preparatorias», huí a la Universidad con la idea de no perdérmela.

No me equivoqué. Fue una revelación, aunque cada miércoles por la tarde acudíamos al anfiteatro con un punto de angustia.

Ya me había leído El ingenioso hidalgo don Quijote de la Mancha y seguía los temas con gran interés. Conocía el sentido de rarezas léxicas como «azor» y contestaba a menudo a las preguntas que formulaba al repleto auditorio. Sin embargo, me di cuenta de que más valía fingir cierta 
simpleza o apatía, porque Nadine Ly siempre pillaba a los alumnos más atentos para pedirles que, por ejemplo, tradujeran — sin previo aviso y con apenas veinte años de edad y siete de aprendizaje del castellano, en el mejor de los casos - alguna frase del prólogo de la Segunda parte: por ejemplo, «había en Córdoba otro loco, que tenía por costumbre de traer encima de la cabeza un pedazo de losa de mármol, o un canto no muy liviano, $y$, en topando algún perro descuidado, se le ponía junto, $y$ a plomo dejaba caer sobre él el peso» ${ }^{1}$. Tampoco se le escapaba el menor bostezo - gracias a sus ojos de azor - y podía fulminar al desdichado o desdichada que cometiera el error de tratar de revitalizar sus capacidades cognitivas por medio de la casmodia. A esta agudeza de quite que nos permitía pasar desapercibidos la llamamos «técnica del ojo del pescaíto frito".

Aprender a leer el Quijote con Nadine Ly resultó toda una oportunidad, y muchos fueron los que envidiaron nuestra suerte, especialmente en España. Al año siguiente, hice una estancia en la Universidad de Alcalá. Allí una amiga, que preparaba su tesis de fin de máster con Ly, se lo contó a una de las profesoras locales, la cual no quiso creerla. Pensaba que Nadine no se dignaba a dirigir ese tipo de trabajos. Fue entonces cuando me di cuenta del prestigio del Departamento de Estudios Ibéricos e Iberoamericanos de la Universidad Michel de Montaigne Bordeaux 3 en el extranjero y, al mismo tiempo, de las expectativas puestas en nosotras por algunos profesores de Literatura del Siglo de Oro y de Lingüística. Expectativas que pocas veces cumpliría en la última disciplina, que nunca fue precisamente mi fuerte, a diferencia del suyo.

Fue lo que descubrí al regresar a Francia, luego de que nuestros rumbos volvieran a cruzarse en las aulas de Bordeaux. Ella daba la clase de Lingüística contemporánea en el marco del apresto para la oposición de la Agrégation (cátedra de instituto), y también la de Literatura del Siglo de Oro, acerca de Los trabajos de Persiles y Sigismunda — que, desde entonces, es uno de mis mejores recuerdos de lectura de textos áureos-. Y fue también la reválida de mi inclinación: entre las risas provocadas por la mujer voladora o los falsos cautivos y aquellos rompecabezas de la morfosintaxis verbal, confieso que su cátedra me ayudó a decantarme por los clásicos

1 Miguel de Cervantes, El ingenioso hidalgo Don Quijote de la Mancha, ed. Luis Andrés Murillo, Madrid, Castalia, 1991, II, p. 35. 
cuando se me ofreció la posibilidad de acometer una tesis de doctorado sobre la América colonial.

Nada más dar los primeros pasos en el mundo de la investigación, me enteré de la larga tradición del hispanismo bordelés, que Nadine Ly nos ilustró en diversas ocasiones ${ }^{2}$. Y no cabe duda de que forma parte de la tradición de excelencia iniciada por eruditos como Georges Cirot, Alfred Morel-Fatio o Ernest Mérimée ${ }^{3}$; más tarde fortalecida por figuras de la talla de Noël Salomon, Maxime Chevalier, Maurice Molho y Joseph Pérez. Los primeros fundaron el Bulletin hispanique (1899), impulsaron la creación de la École de Hautes Études Hispaniques (1909) en Madrid - germen de la actual Casa de Velázquez (1928) - e introdujeron el hispanismo en mi Universidad.

Nadine Ly prolongaría aquella escuela desde la década de los setenta. Junto con el americanista Yves Aguila fundó el grupo de investigación AMERIBER y el seminario del GRIAL (Groupe de Recherche Interdisciplinaire d'Analyse Littérale), dos pilares de una trayectoria cifrada en una valiosísima obra en torno a la poesía de Góngora y la creación de la «literalidad». La avalan asimismo un sinnúmero de reconocimientos: directora de la Escuela Doctoral de la Universidad Michel de MontaigneBordeaux 3, vicerrectora de la misma institución, presidenta de la Société des Hispanistes Français, miembro del consejo científico de la Casa de Velázquez, co-directora del Bulletin hispanique con Federico Bravo y miembro correspondiente de la Real Academia Española. También ha sido condecorada con la Légion d'Honneur (2008), y, en España, con el Lazo de Dama de la Orden de Isabel la Católica (1982).

Hace no demasiados años, a la alumna de parecer impasible que trataba de refrenar un eventual bostezo fruto de ocho largas horas de clase que culminaban con el estudio de la Segunda parte del ingenioso caballero Don Quijote de la Mancha, Nadine Ly le abrió las puertas del Bulletin hispanique para que coordinara un monográfico sobre La épica en el mundo

2 Pierre Civil, "Réflexions sur l'hispanisme à l'occasion du centenaire de la Casa de Velázquez», Mélanges de la Casa de Velázquez [En ligne], 50-1 | 2020, mis en ligne le 06 mars 2020, consulté le 04 novembre 2021. URL : http://journals.openedition. org/mcv/12127; DOI : https://doi.org/10.4000/mcv.12127

3 Georges Cirot, «Les Études hispaniques à l'Université de Bordeaux», Bulletin Hispanique, I, 4 (1899), pp. 255-264. 
hispánico (Siglo de Oro) ${ }^{4}$, con el apoyo de la Universidad Bordeaux Montaigne y la del travieso Califato de Córdoba.

Solo queda a esta servidora darle infinitas gracias a una gran profesora por transmitirle la exigencia, el amor a la sutileza y al ingenio y la aspiración a la sabiduría. Y más aún por la oportunidad brindada a tantos alumnos, herederos de la antorcha del hispanismo bordelés desde los diferentes espacios científicos que ideó y concretó en nuestra alma mater.

Concluyo afirmando que hoy, gracias a Nadine Ly y como se suele decir en Venezuela, «sabemos más que el pescado frito».

4 Lise Segas, «Avant-Propos», Bulletin hispanique, CXXI, 1 (2019), pp. 9-16. 